Дядюк Тетяна Юхимівна вчитель української мови та літератури, Володимир-Волинська ЗОШ № 5 ім. А. Кореневського, вул. Луцька, 241, м. Володимир - Волинський, 44700, тел. (03342) 3-05-55, e-mail: tanyadja@ukr.net, https://orcid.org/0000-0001-8209-4773

\title{
ФОРМУВАННЯ ЖИТТЕВИХ КОМПЕТЕНТНОСТЕЙ ЯК РЕЗУЛЬТАТ ІНТЕГРУВАННЯ ПРЕДМЕТІВ ГУМАНІТАРНОГО ЦИКЛУ
}

Анотація. Сьогодні великого значення набувають такі якості особистості, як соціальна відповідальність, адекватне сприйняття і мобільне реагування на нові факти, самостійність і оперативність у прийнятті рішень, готовність до демократичного спілкування, соціальних дій, включно із захистом своїх прав, здатність швидко адаптуватися до нових умов та інші складові конкурентноздатності особистості.

Інтеграція предметів гуманітарного циклу сприяє вирішенню багатьох проблем: інформаційна перенасиченість, різні підходи до викладу матеріалу, нерозривність історичних i літературних процесів. Міжпредметні зв'язки сприяють формуванню в учнів цілісного уявлення про події в минулому, допомагають їм використовувати свої знання при вивченні різних предметів, являються засобом оволодіння учнями культурного досвіду.

Формування компетентностей у дитини залежить від індивідуальної майстерності педагога, вміння спроектувати навчально-виховний процес, способи і характер взаємодії. Інтегровані уроки розвивають моральну культуру, творчі здібності учнів.

Цілісність інтегрованого уроку характеризується взаємозумовленістю цілей, змісту навчання, способів і засобів їх реалізації. Інтеграція в галузі природничих наук пов'язана, перш за все, з розширенням меж і мотивацій активної діяльності школярів, інтеграція в області гуманітарних дисциплін сприяє світоглядному розвитку особистості, усвідомленню причинно- наслідкових зв'язків між явищами суспільного життя і мистецтвом.

Інтегровані уроки дозволяють розвивати аналітичні здібності, а також допомагають вибрати правильну особистісну позицію у складній соціальній ситуації, що сприятиме успішній соціалізації особистості.

Ключові слова: компетентність, інтегрований урок, інтеграція.

Diadiuk Tetiana Iukhymivna Teacher of Ukrainian language and literature at Volodymyr-Volynska Secondary School № 5, Lutska St., 241, Volodymyr - Volynsky, 44700, tel. (033) 423-05-55, e-mail: tanyadja@ukr.net, https://orcid.org/0000-0001$8209-4773$ 


\section{FORMATION OF LIFE COMPETENCES AS A RESULT OF INTEGRATING HUMANITIES SUBJECTS}

Abstract. Nowadays such personal qualities as social responsibility, appropriate perception and quick reaction to new facts, independence and efficiency in decision making, ability to conduct democratic communication, take social actions including protection of one's rights, ability to adapt quickly to new conditions and other components of personal competitiveness become increasingly important.

Integration of subjects of the humanities cycle helps to solve many problems: information overload, different approaches to the presentation of the material, inseparability of historical and literary processes. Interdisciplinary links contribute to the formation of a holistic view of the events in the past, help students to use their knowledge in the study of different subjects, are a means of mastering the students' cultural experience.

The formation of competencies in a child depends on the individual skill of the teacher, the ability to design the educational process, ways and nature of interaction. Integrated lessons develop the moral culture and creative abilities of students.

Integrity of an integrated lesson is characterized by the interdependence of goals, learning content, ways and means of their implementation. Integration in the field of natural sciences is connected, first of all, with the expansion of the boundaries and motivation of the active activity of students; integration in the field of humanities disciplines contributes to the worldview development of the personality, awareness of the cause-and-effect relations between the events of social life and the art.

Integrated lessons allow to develop analytical skills, as well as help to choose the right personal position in a difficult social situation, which will contribute to the successful socialization of the individual.

Keywords: competence, integrated lesson, integration.

Постановка проблеми. У всіх сферах діяльності все більшого значення набувають такі якості особистості, як соціальна відповідальність, адекватне сприйняття і мобільне реагування на нові факти, самостійність і оперативність у прийнятті рішень, готовність до демократичного спілкування, соціальних дій, включно із захистом своїх прав, здатність швидко адаптуватися до нових умов та інші складові конкурентноздатності особистості. Першочерговість визначається не у володінні вузькоспеціалізованими знаннями, а у формуванні основних типів ключових компетентностей, оскільки наразі відмічається схильність до збільшення об'єму навчальної інформації, що дає учням із середніми здібностями можливість у кращому випадку запам'ятати, а не усвідомити отриману інформацію.

Аналіз останніх досліджень і публікацій. Важливі аспекти формування основних типів ключових компетентностей та інтеграції предметів гуманітарного циклу висвітлюються такими українськими ученими як М. Жигайло, О. Савченко, Г. Філь та ін. 
Мета статті - дослідження особливостей та механізмів інтеграції предметів гуманітарного циклу.

Виклад основного матеріалу. Інтеграція предметів гуманітарного циклу сприяє вирішенню багатьох проблем: інформаційна перенасиченість, різні підходи до викладу матеріалу, нерозривність історичних і літературних процесів. Міжпредметні зв'язки сприяють формуванню в учнів цілісного уявлення про події в минулому, допомагають їм використовувати свої знання при вивченні різних предметів, являються засобом оволодіння учнями культурного досвіду.

Визначені основні компетентності, які повинні бути у випускника школи.

Серед них виділяються найсуттєвіші, а саме :

- комунікативна - спосіб передачі інформації, здатність аналізувати і діяти 3 позиції окремої області людської культури;

- самоменеджмент - самоосвіта, самоорганізація;

- інформаційна- способи прийому, зберігання, засвоєння і передачі інформації;

- соціалізація як результат засвоєння компетентностей і виявляється у здатності діяти, вступати в комунікацію 3 метою бути зрозумілим, а також розвиток організаторських та лідерських якостей.

Формування компетенцій у дитини залежить від індивідуальної майстерності педагога, вміння спроектувати навчально-виховний процес, способи і характер взаємодії. Тут варто нагадати про особистий інструментарій педагога педагогічні ідеї та технології, співвідносні з уже існуючими культурними аналогами, що $\epsilon$ складовою педагогічної культури. Освітній процес вибудовується i технології навчання підбираються таким чином, аби кожен учень був задіяний в активну освітню діяльність в зоні його найближчого розвитку, незважаючи на залежність від своїх психофізіологічних особливостей і навчальних здібностей.

Література - один із предметів гуманітарного циклу. Вона покликана виховати всебічно розвинену людину, активізувати розумову діяльність учнів, формувати узагальнені знання та вміння, виховувати естетично підготовлену особистість. Вирішити всі ці питання допоможе інтеграція предметів : і елективні курси, і позакласна робота з предметів гуманітарного циклу, і інтегровані уроки.

Інтегровані уроки розвивають моральну культуру, творчі здібності учнів. На таких заняттях школярі стають більш активними, самостійними у своїх судженнях, мають власну точку зору і вміють аргументовано іiі відстоювати. Спробую узагальнити досвід інтеграції на уроках літератури.

В умовах модернізації системи освіти особливу актуальність набуває пошук нових моделей навчання і виховання школярів, розробка нових курсів змісту навчальних предметів, альтернативних і варіативних підходів до вже відомих, традиційних методів і прийомів навчання, виховання і розвитку учнів.

Зокрема, гуманізація, демократизація і гуманітаризація школи виводять на перший план, як пріоритетну, проблему розробки педагогічних основ ефективного виховання і розвитку учнів засобами інтегрованих курсів предметів мистецтв і гуманітарних предметів. Зміст, новизна інтеграції, взаємозв'язок 
різних навчальних предметів, виходячи 3 вимог державних стандартів, умов модернізації системи освіти, повинні, перш за все, визначатись правильним методологічним підходом. А це означає розгляд необхідності i важливості розкриття проблеми взаємодії різних видів мистецтва, літератури, історії, іноземних мов у навчальному процесі в працях, висловлюваннях відомих філософів, педагогів, психологів, діячів мистецтв минулого і сучасності.

Як свідчить аналіз літературних джерел, філософи, педагоги, письменники, музиканти і художники часто висловлювались про користь комплексної дії різних видів мистецтва на особистість, на формування іï духовного світу, естетичних потреб та інтересів.

Свого часу про це переконливо писали Іван Котляревський,Тарас Шевченко, Леся Українка, Панас Мирний, Василь Сухомлинський, Костянтин Ушинський. Так І. Котляревський продемонстрував у своїх творах ( «Наталка Полтавка» та «Енеїда») спосіб трансформаціії народного мистецтва у літературну творчість. Про мистецтво як чинник розвитку особистості говорив народний поет, художник, філософ XIX століття Т. Г. Шевченко: «I всі вони так велично-прості і прекрасні, що коли б воскрес сліпець хіоський та почув хоча б одну 3 них (пісень) від такого ж, як і він сам, кобзаря чи лірника, то розбив би вщент свій козуб, названий лірою, і пішов би в міхоноші до найбільшого нашого лірника» [1, С. 37].

Панас Мирний, видатний письменник XIX століття, зазначав, що «спів - то мова душі, то голос серця» [1, С. 48]. Про надзвичайний вплив мистецтва на людину неодноразово писала, звертаючись до митців, і Леся Українка : «Шукай, відбирай, перевтілюй у власній творчості насамперед те, що являє прекрасне, що пов'язане 3 красою народного сприймання, народної фантазії i народного світогляду, а не те потворне, негарне, що повинне лише відтінювати велич прекрасного, закладеного в народові» [2, С. 18].

Досить виразно про мову як засіб не тільки спілкування, а й дієвого вираження внутрішнього світу через образно-художні засоби сказав К. Ушинський, оскільки саме поєднання впливу слова, музики, мистецтва i природи має неабияке значення для розвитку особистості. Як відомо естетичне виховання як складна філософська i педагогічна категорія включає в себе виховання здатності сприйняття $\mathrm{i}$ правильного розуміння прекрасного в дійсності( природі, праці, суспільних відносинах, вчинках людей) і в мистецтві, розвитку естетичних поглядів, смаків і відчуттів, потреб і здатності брати участь у створенні ідеалу в мистецтві і житті. Задачі естетичного виховання, як одного із засобів багатогранного розвитку особистості, найбільш успішно вирішуються при паралельній взаємодії різних видів мистецтва, при вивченні основ мистецтва слова, звуку, ліній, фарб і т.д. Художнє виховання,як його визначає педагогічна наука останніх десятиліть, $є$ «розвиток у підростаючих поколінь любові та інтересів до мистецтва, а також навичок і вмінь художньої діяльності( хорового співу, гри на музичних інструментах, малювання, художнього читання і т .д.), являючись таким чином, частиною естетичного виховання» [3, С. 5-6].

Естетичне виховання передбачає, перш за все,комплексне використання таких мистецтв як живопис і література, рідна мова і фольклор, а також народна 
творчість (декоративно-прикладне мистецтво), архітектура, музика і спів.

Чимало учителів української мови в середніх школах намагаються розширити програму свого предмету, вводячи у неї вивчення поетичної народної творчості і поетичної літератури до сучасної включно. Це може бути цикл уроків, об'єднаних однією темою. Наприклад, «Стоїчна українська поезія», «Митець i суспільство», «Поетичне самовираження українців» .

Досить цікавими є погляди Юрія Лотмана, який вважає, що мистецтво створює додатковий шар реальності, який надає людині більше свободи. Мистецтво дозволяє експериментувати, зображати не лише дещо складно реалізоване чи заборонене [4, С. 130], а тим самим виховувати естетичні смаки, ідейні принципи, чітку світоглядну позицію. Пояснюючи розуміння естетики як науки про красу, естетичне сприйняття, він справедливо стверджує, що «область мистецтва через свою знаково-символічну природу завжди включає почуття відстороненості, а це неминуче вводить механізм етичної оцінки» [4, С. 131].

Образотворче мистецтво стало активно залучатись як засіб естетичного виховання і більш успішного формування зорових образів на уроках української мови та літератури останнім часом. Наприклад, програмою передбачено цикли уроків розвитку зв'язного мовлення, на яких учням пропонуються для огляду, опису, аналізу репродукції робіт Венеціанова, Перова, Рєпіна, Бродського та інших. Метою таких занять $є$ намір зробити сприйняття дійсності більш образним, яскравим, емоційно насиченим і різнобарвним.

Отож, у чому переваги інтегрованого уроку? Серед таких переваг варто означити наступні:

- на такому уроці можна створити сприятливі умови для розвитку різних інтелектуальних вмінь учнів;

- через нього можна вийти на формування більш широкого мислення, навчити застосовувати теоретичні знання у практичній діяльності, у конкретних життєвих, професійних і наукових ситуаціях;

- Інтегровані уроки наближають процес навчання до життя, натуралізують його, оживляють духом часу, наповнюють смислом;

- Інтегровані уроки допомагають учням знайти i осягнути єдині закономірності різних наук;

- такі уроки взаємозбагачують учителів, сприяють їх творчому зросту.

Цілісність інтегрованого уроку характеризується взаємозумовленістю цілей, змісту навчання, способів і засобів їх реалізації. I якщо інтеграція в галузі природничих наук пов'язана, перш за все, 3 розширенням меж i мотивацій активної діяльності школярів, то інтеграція в області гуманітарних дисциплін сприяє світоглядному розвитку особистості, усвідомленню причиннонаслідкових зв’язків між явищами суспільного життя і мистецтвом.

Висновки. Таким чином, інтегровані уроки не тільки дозволяють розвивати аналітичні здібності, а й допомагають вибрати правильну особистісну позицію у складній соціальній ситуації, що сприятиме успішній соціалізації особистості. Тож подальше дослідження та практичне втілення інструментів інтегрування предметів гуманітарного циклу сприятиме розвитку особистості школяра. 


\section{Лimepamypa:}

1. Ващенко Г. Вибрані педагогічні твори: у 2 т. Т.1. Дрогобич: Відродження,1977.245 с.

2. Машенко М. Музика і живопис на уроках літератури. К.: Радянська школа, 1971.75 с.

3. Педагогическая инноватика: проблемы стратегии и тактики [Текст] : монография / В. И. Загвязинский, Т. А. Строкова ; Российская Федерация, М-во образования и науки, Гос. образовательное учреждение высш. проф. образования Тюменский гос. ун-т. Тюмень : Изд-во Тюменского гос. ун-та, 2011. 174 с.

4. Лотман Ю.М. Культура и взрыв. Семиосфера. Санкт-Петербург. «Искусство-СПБ. C.129-137

\section{References:}

1. Vashchenko, G. (1977). Vibrani pedagogichni tvori [Selected pedagogical works]. Drohobych: Vidrodzhennja [in Ukrainian].

2. Mashenko, M. (1971). Muzika i zhivopis na urokah literaturi [Music and painting in literature lessons]. Kiev: Radjans'ka shkola [in Ukrainian].

3. Zagvyazinsky, V.I., Strokova, T.A. (2011) Pedagogicheskaja innovatika: problemy strategii $i$ taktiki [Pedagogical innovation: problems of strategy and tactics]. Tyumen Izd-vo Tjumenskogo gos. un-ta [in Russian].

4. Lotman, Yu.M. Kul'tura i vzryv. Semiosfera [Culture and explosion. Semiosphere]. St. Petersburg: Iskusstvo-SPB [in Russian]. 